\title{
Correction to: Local House Price Paths: Accelerations, Declines, and Recoveries
}

\author{
Alexander N. Bogin ${ }^{1} \cdot$ William M. Doerner $^{1} \cdot$ William D. Larson $^{1}$ \\ Published online: 7 November 2019 \\ (C) This is a U.S. government work and not under copyright protection in the U.S.; foreign copyright protection \\ may apply 2019
}

\section{Correction to: The Journal of Real Estate Finance and Economics (2019) 58:201 https://doi.org/10.1007/s11146-017-9643-y}

The article Local House Price Paths: Accelerations, Declines, and Recoveries written by Alexander N. Bogin, William M. Doerner and William D. Larson was originally published electronically on the publisher's internet portal (currently SpringerLink) on December 2017 without open access.

With the author(s)' decision to opt for Open Choice, the copyright of the article will remain as (C) This is a U.S. government work and its text is not subject to copyright protection in the United States; however, its text may be subject to foreign copyright protection 2019 and the article is forthwith distributed under the terms of the Creative Commons Attribution 4.0 International License (http://creativecommons. org/licenses/by/4.0/), which permits use, duplication, adaptation, distribution and reproduction in any medium or format, as long as you give appropriate credit to the original author(s) and the source, provide a link to the Creative Commons license and indicate if changes were made.

The original article has been corrected.

The online version of the original article can be found at https://doi.org/10.1007/s11146-017-9643-y

William M. Doerner

william.doerner@fhfa.gov

Alexander N. Bogin

alexander.bogin@fhfa.gov

William D. Larson

william.larson@fhfa.gov

1 Federal Housing Finance Agency, Office of Policy Analysis and Research, 400 7th Street SW, Washington, DC 20219, USA 
Open Access This article is licensed under a Creative Commons Attribution 4.0 International License, which permits use, sharing, adaptation, distribution and reproduction in any medium or format, as long as you give appropriate credit to the original author(s) and the source, provide a link to the Creative Commons licence, and indicate if changes were made. The images or other third party material in this article are included in the article's Creative Commons licence, unless indicated otherwise in a credit line to the material. If material is not included in the article's Creative Commons licence and your intended use is not permitted by statutory regulation or exceeds the permitted use, you will need to obtain permission directly from the copyright holder. To view a copy of this licence, visit http://creativecommons.org/licenses/by/4.0/.

Publisher's Note Springer Nature remains neutral with regard to jurisdictional claims in published maps and institutional affiliations. 